\title{
Synergistic Interaction of CLAVATA1, CLAVATA2, and RECEPTOR-LIKE PROTEIN KINASE 2 in Cyst Nematode Parasitism of Arabidopsis
}

\author{
Amy Replogle, ${ }^{1}$ Jianying Wang, ${ }^{1}$ Vitoria Paolillo, ${ }^{1}$ John Smeda, ${ }^{1}$ Atsuko Kinoshita, ${ }^{2}$ Amanda Durbak, ${ }^{3}$ \\ Frans E. Tax, ${ }^{3}$ Xiaohong Wang, ${ }^{4}$ Shinichiro Sawa, ${ }^{5}$ and Melissa G. Mitchum ${ }^{1}$ \\ ${ }^{1}$ Division of Plant Sciences and Bond Life Sciences Center, University of Missouri, Columbia 65211, U.S.A.; ${ }^{2}$ RIKEN Plant \\ Science Center, 1-7-22 Suehiro-cho, Tsurumi-ku, Yokohama, Kanagawa 230-0045, Japan; ${ }^{3}$ Department of Molecular and \\ Cellular Biology and School of Plant Sciences, University of Arizona, Tucson 85721, U.S.A.; ${ }^{4}$ United States Department of \\ Agriculture-Agricultural Research Service, Robert W. Holley Center for Agriculture and Health and Department of Plant \\ Pathology and Plant-Microbe Biology, Cornell University, Ithaca, NY 14853, U.S.A.; ${ }^{5}$ Graduate School of Science and \\ Technology, Kumamoto University, Kumamoto, Japan
}

Submitted 16 May 2012. Accepted 3 July 2012.

\begin{abstract}
Plant-parasitic cyst nematodes secrete CLAVATA3 (CLV3)/ ENDOSPERM SURROUNDING REGION (CLE)-like effector proteins. These proteins act as ligand mimics of plant CLE peptides and are required for successful nematode infection. Previously, we showed that the CLV2/ CORYNE (CRN) heterodimer receptor complex is required for nematode CLE signaling. However, there was only a partial reduction in nematode infection when this signaling was disrupted, indicating that there might be additional nematode CLE receptors. In this study, we demonstrate that CLV1 and RECEPTOR-LIKE PROTEIN KINASE 2/TOADSTOOL2 (RPK2), two additional receptors that can transmit the CLV3 signal independent of CLV2/CRN for shoot apical meristem maintenance, also play a role in nematode CLE perception. Localization studies showed that both receptors are expressed in nematode-induced syncytia. Infection assays with $c l v 1$ and rpk2 single mutants revealed a decrease in both nematode infection and syncytium size. Significantly, further reduction in nematode infection was observed when rpk2 was combined with $\operatorname{clv} 1$ and $\operatorname{clv} 2$ mutants. Taken together, our results indicate that parallel signaling pathways involving CLV1, CLV2, and RPK2 are important for nematode parasitism.
\end{abstract}

Feeding cells, called syncytia, are unique cell types induced in plants by cyst nematodes as they start to feed from a selected cell near the root vasculature. Syncytia form by the coalescence of adjacent cells and are characterized by an increase in metabolic activity, dense cytoplasm, reduced vacuole size, proliferation of other cellular organelles, cell wall thickening, and formation of ingrowths along walls adjacent to the xylem vessels to increase membrane surface for solute uptake (Hussey and Grundler 1998). Cyst nematodes are completely dependent on syncytia for nutrient acquisition in

Corresponding author: M. G. Mitchum; Telephone: +1.573 .882 .6152 ; Fax: +1.573.884.9676; E-mail: goellnerm@ missouri.edu

* The $\boldsymbol{e}$-Xtra logo stands for "electronic extra" and indicates that one supplementary figure is published online.

(C) 2013 The American Phytopathological Society order to complete their life cycle. If syncytia formation is disrupted, as seen in some resistant cultivars, subsequent nematode growth and development is arrested (Sobczak et al. 2005). Initiation and maintenance of syncytia occurs in response to nematode-secreted effector proteins that are produced in the esophageal gland cells, packaged into secretory granules, and released from the nematode through their stylet (Davis et al. 2008). Nematode secreted effector proteins interact with host plant cells and alter plant gene expression to metabolically and developmentally reprogram normal root cells to de-differentiate into syncytia (Gheysen and Mitchum 2011; Szakasits et al. 2009).

One tactic that nematodes employ to reprogram host plant cells for the formation of syncytia is to secrete effectors that mimic host plant proteins. In cyst nematodes, some of these effector proteins have been identified as CLAVATA3 (CLV3)/ ENDOSPERM SURROUNDING REGION (CLE)-related peptides (Lu et al. 2009; Olsen and Skriver 2003; Wang et al. 2005; Wang et al. 2010, 2011). CLE are a class of plant peptide hormones that have been identified in a number of different monocotyledonous and dicotyledonous plant species, including rice, wheat, cotton, clover, tomato, soybean, maize, and Arabidopsis (Cock and McCormick 2001), which are involved in regulating stem cell differentiation and developmental pattern formation (Katsir et al. 2011). In Arabidopsis, CLE constitute a 32-member family that can be classified into A-type and B-type CLE peptides (Ito et al. 2006; Jun et al. 2008; Whitford et al. 2008). A-type CLE peptides regulate differentiation in root and shoot apical meristems, whereas B-type CLE peptides (CLE41 to CLE44) suppress differentiation in the vascular meristem (Etchells and Turner 2010; Hirakawa et al. 2008; Whitford et al. 2008). Expression of both A- and B-type CLE peptides has been detected in a variety of plant organs; however, many display distinct cell-specific expression patterns (Jun et al. 2010; Sharma et al. 2003). In addition, multiple CLE have overlapping spatial and temporal expression patterns, which are thought to allow for synergistic interactions and fine tuning of developmental and environmental cues for plant pattern formation (Whitford et al. 2008).

In Arabidopsis, plant CLE peptides are predominantly recognized by members of the leucine-rich repeat (LRR) receptor-like kinase (RLK) family (Shiu and Bleecker 2001). In the shoot apical meristem (SAM), stem cells secrete CLV3, which 
restricts expression of WUSCHEL (WUS), a gene encoding a homeodomain transcription factor that resides in the organizing center of the SAM to promote stem cell proliferation (Fletcher et al. 1999). The downregulation of WUS was shown to result in differentiation of stem cells that are displaced to the peripheral zone of the SAM (Reddy and Meyerowitz 2005; Yadav et al. 2010). The CLV3-WUS pathway is kept in balance due, in part, to the fact that WUS also induces the expression of $C L V 3$, thereby establishing a negative feedback loop for stem cell maintenance (Brand et al. 2000; Schoof et al. 2000). Previous studies showed that the LRR-RLK, CLV1, and LRR-receptor-like transmembrane protein, CLV2, which interacts with a membrane-associated putative serine threonine kinase, CORYNE (CRN), are able to transmit the CLV3 signal to restrict the expression of WUS in the SAM (Bleckmann et al. 2010; Guo et al. 2010; Miwa et al. 2008; Muller et al. 2008; Ogawa et al. 2008; Schoof et al. 2000; Yadav et al. 2010; Zhu et al. 2010). However, the clv1 clv2 double mutant could not phenocopy the enlarged meristems of the $\operatorname{clv} 3$ mutant, indicating that additional receptors were involved in CLV3-mediated stem cell maintenance (Kinoshita et al. 2010). Recently, Kinoshita and associates (2010) identified a third signaling pathway involving the LRR-RLK RECEPTOR-LIKE PROTEIN KINASE 2/TOADSTOOL2 (RPK2), that can transmit the CLV3 signal independent of CLV1 and CLV2-CRN. In fact, the clv1 clv2 rpk2 triple mutant nearly phenocopies the clv3 mutant (Kinoshita et al. 2010).

In the root apical meristem (RAM), CLE40, the closest homolog to $C L V 3$, is expressed in the differentiating columella cells and restricts expression of the WUS-related homeobox 5 (WOX5) to the quiescent center (Sarkar et al. 2007; Stahl et al. 2009). WOX5 was shown to be required for the maintenance of the stem cells in the distal region of the RAM that will develop into columella cells (Sarkar et al. 2007). This regulation is dependent on the receptor kinase ARABIDOPSIS HOMOLOG OF CRINKLY4 (ACR4); however, direct binding of CLE40 to ACR4 has not yet been shown (Stahl et al. 2009). The WOX5/CLE40 signaling pathway is only involved in determining the cell fate of the distal stem cell pool, indicating that other CLE signaling pathways may exist to determine cell fate of the proximal stem cell pool. Accordingly, a number of Arabidopsis CLE genes are expressed in roots (Jun et al. 2010; Sharma et al. 2003). Overexpression of some of these CLE genes was shown to cause premature termination of the primary root meristem (Fiers et

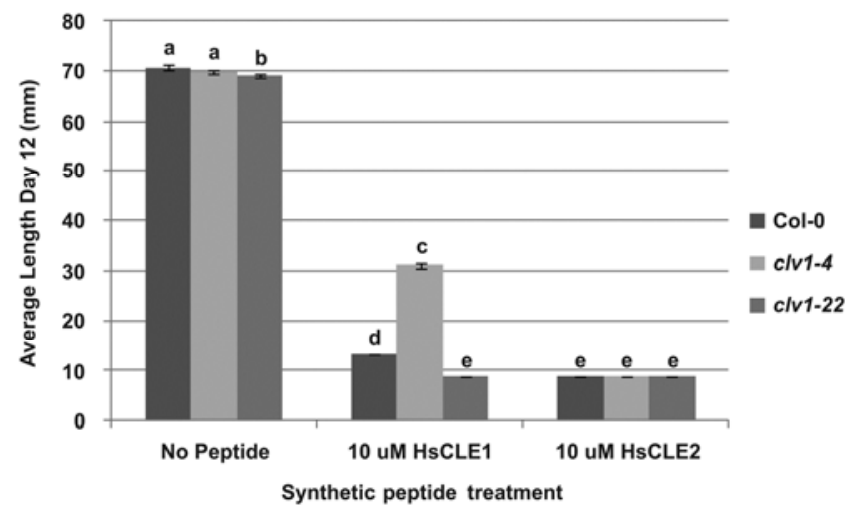

Fig. 1. Effect of cyst nematode CLAVATA3 (CLV3)/ENDOSPERM SURROUNDING REGION (CLE) peptides on $c l v 1$ mutants. Seedlings grown for 12 days on medium with or without the indicated synthetic nematode 12 -amino acid CLE motif peptides. Data represent the mean \pm standard error ( $n=13$ for Col-0, 14 for $c l v 1-4$, and 13 for $c l v 1-22)$. Means with different letters are significantly different $(P \leq 0.05)$. Data are representative of two biological replicates. al. 2004; Meng et al. 2010; Strabala et al. 2006) in a CLV2CRN- or RPK2-dependent manner (Casamitjana-Martinez et al. 2003; Fiers et al. 2005; Kinoshita et al. 2010; Meng et al. 2010; Miwa et al. 2008).

We previously characterized $C L E$-like genes from the soybean cyst nematode (SCN; Heterodera glycines) (Wang et al. 2005; Wang et al. 2010) and the beet cyst nematode (BCN; $H$. schachtii) (Wang et al. 2011). Thus far, CLE from both SCN and $\mathrm{BCN}$ fall into the A-type class of plant CLE peptides (Wang et al. 2010, 2011). An RNAi approach targeting nematode CLE genes showed that nematode CLE peptides are important for successful infection of host plant roots (Bakhetia et al. 2007; Patel et al. 2008). In addition, we showed that the CLV2-CRN receptor complex is involved in nematode CLE perception and that this perception is important for proper feeding cell formation (Replogle et al. 2011). However, we only saw a partial reduction in nematode numbers and syncytia size in the $\operatorname{clv} 2$ and $\mathrm{Crn}$ mutant backgrounds, suggesting that there may be additional candidate receptors for nematode CLE perception. In this study, we investigate a role for CLV1 and RPK2 in nematode CLE signaling.

\section{RESULTS}

\section{A dominant negative allele of $C L V 1$ is partially resistant to} HsCLE1 but not HsCLE2 peptide application.

We previously showed that the short-root phenotype caused by exogenous application of 12-amino acid (aa) peptides corresponding to the CLE motifs of the BCN (HsCLE) CLE is dependent on perception by CLV2 and CRN (Replogle et al. 2011). In the SAM, genetic evidence suggests that CLV1 acts independently of CLV2 and CRN to transmit the CLV3 signal (Muller et al. 2008). However, biochemical data suggests that CRN acts as a scaffolding protein to promote association of CLV2 with CLV1 to form a receptor complex (Betsuyaku et al. 2011; Bleckmann et al. 2010; Guo et al. 2010; Zhu et al. 2010). In Arabidopsis, it was shown that the short root phenotype caused by overexpression or exogenous application of some plant CLE peptides is dependent on CLV2 or CRN signaling (Fiers et al. 2005; Meng and Feldman 2010; Miwa et al. 2008; Muller et al. 2008).

A role for a CLV1-CLE signaling pathway in the RAM has been largely overlooked because CLVI expression is thought to be restricted to the center of the SAM, and its function is thought to be confined to stem cell specification in the shoot (Clark et al. 1997; Fletcher et al. 1999). To determine whether or not CLV1 might play a role in cyst nematode CLE perception, we screened two mutant alleles of clvl in Arabidopsis for resistance to the HsCLE1 and HsCLE2 12-aa peptides (Fig. 1). The $c l v 1$ alleles vary greatly in phenotypic severity, ranging from weak alleles with only modest increases in stem cell number to strong alleles with 1,000-fold more undifferentiated cells compared with the wild type (Clark et al. 1993). All of the clvl alleles that exhibit a strong or intermediate phenotype contain missense mutations within the coding sequence and are not true null alleles (Clark et al. 1997). This led to the finding that the stronger $c l v l$ alleles are dominant negative and likely interfere with additional receptor kinases within the meristems (Dievart et al. 2003). In our peptide screen, we used clv1-22 as the null allele with a weak floral phenotype and clv1-4 as the dominant negative allele with a strong floral phenotype (Clark et al. 1995; Durbak and Tax 2011; McKelvie 1962). Wild-type and mutant seed were grown on vertical plates in the absence of exogenous peptide or in the presence of $10 \mu \mathrm{M}$ HsCLE peptides, and roots were measured 12 days after germination. In the absence of peptide, we noted a slight reduction in root length of the $c l v 1-22$ mutant but not the clv1-4 
mutant compared with the wild type. In the presence of peptide, we observed that HsCLE1 and HsCLE2 strongly inhibit $c l v 1-22$ root growth (Fig. 1). In contrast, roots of $c l v 1-4$ were partially resistant to HsCLE1 peptide application but sensitive to exogenous application of HsCLE2 (Fig. 1). This result supports the idea that CLV1 interacts with other receptor kinases in the root meristem to transmit CLE signals. In addition, these data indicate that HsCLE1 and HsCLE2 may be perceived in the root by a CLV1-independent pathway and possibly differ in their receptor specificities.

\section{The rpk2 mutants are insensitive to nematode CLE peptide application.}

Until recently, the overproliferation of stem cells in the $c l v 3$ mutant could not be phenocopied by single null or intermediate $c l v 1$ mutants or double mutants of $c l v 1$ and $c l v 2-c r n$. This prompted researchers to identify additional CLV3 receptors by screening an ethyl methanesulfonate (EMS) mutagenized population for insensitivity to $5 \mu \mathrm{M}$ AtCLV3 peptide application (Kinoshita et al. 2010). Fourteen CLV3-insensitive mutants were identified, one of which turned out to be a new allele of $R P K 2$ (Kinoshita et al. 2010). RPK2 was first identified as TOADSTOOL2 (TOAD2), which acts redundantly with RPK1 for embryonic pattern formation in Arabidopsis (Nodine et al. 2007). Around the same time, RPK 2 was also shown to be involved in anther development by controlling tapetal cell fate (Mizuno et al. 2007). These three independent studies highlight the important roles that RPK2 plays in different aspects of plant growth and development. Most homozygous rpk2 mutants are male sterile due to the role RPK2 plays in anther development but $r p k 2-5$ is a unique allele in that it does not have the male sterile phenotype but is still resistant to AtCLV3 peptide (S. Sawa, unpublished data), similar to other rpk2 mutants (Kinoshita et al. 2010). In exogenous peptide assays, we determined that $r p k 2-5$ was resistant to HsCLE1 and HsCLE2 peptide treatment (Fig. 2). These data indicate that RPK2 plays an important role in nematode CLE peptide perception.

\section{$C L V 1$ and $R P K 2$ expression is induced in nematode feeding sites.}

RLK proteins make up one of the largest groups of proteins in Arabidopsis, comprising more than $1 \%$ of all protein-encoding genes and more than $50 \%$ of all kinases (Shiu and Bleecker 2001). Of these, LRR receptor kinases are the most highly represented, making up more than half of all RLK. Many of these proteins share a large degree of functional similarity, and their divergent developmental roles appear to be largely driven by differences in transcription. In order for CLV1 or RPK2 to be able to perceive the nematode CLE as a ligand mimic, they must be expressed in the correct spatial and temporal context.

It has long been assumed that CLV1 expression is exclusively in shoot and floral meristems (Clark et al. 1997; Meng et al. 2010). However, this idea was based on unpublished data described by Clark and associates (1997) that CLVI mRNA could not be detected in the root meristem during embryo development. Since this initial identification and characterization, papers have been referring to these data without confirming expression using quantitative real-time polymerase chain reaction (qPCR) or promoter-reporter lines. Analysis of root cell-type-specific expression using microarrays indicates that CLV1 is expressed in roots (Birnbaum et al. 2003; Brady et al. 2007). In uninfected Arabidopsis roots expressing CLV1: $\beta$ glucuronidase $(G U S)$, we observed expression in the RAM and throughout the root vasculature starting at the zone of maturation where root hair initiation begins (Fig. 3A). GUS expression in these transgenic lines was recently shown to reflect the cell-specific expression pattern of endogenous CLVI tran- scripts in developing fruit (Durbak and Tax 2011). To determine whether CLV1 is expressed in nematode feeding sites, transgenic Arabidopsis seedlings expressing CLV1:GUS were infected with BCN and monitored during nematode development. GUS expression was detected in feeding sites fed upon by second-stage juveniles (J2) during early stages of syncytium development (Fig. 3B). GUS expression reached its peak once nematodes reached late $\mathrm{J} 2$ parasitic stages but remained detectable in the feeding sites of third-stage juveniles (J3s) (Fig. $3 \mathrm{C})$. By the time the nematodes reached the fourth-stage juvenile (J4) life stage, GUS expression was either weak or absent in feeding sites (Fig. 3D).

In Arabidopsis, RPK2 was shown to be expressed during early embryogenesis, in the inflorescence meristem, floral meristem, floral organ primordium, vascular bundles, and the RAM (Kinoshita et al. 2010; Mizuno et al. 2007; Nodine et al. 2007). Upon closer inspection of the RAM, both RPK2 transcripts and RPK2-green fluorescent protein (GFP) fusion proteins were detected in the stem cell pool of the root, including the quiescent center, but were not found to be in the columella cells (Kinoshita et al. 2010). In roots, $R P K 2$ expression appears to be specific to the RAM (Kinoshita et al. 2010; Mizuno et al. 2007), indicating that it may be involved in RAM maintenance mediated by plant CLE. Therefore, we were interested to see whether nematode infection could induce $R P K 2$ expression in other parts of the root. We utilized transgenic Arabidopsis expressing RPK2:GUS and the pRPK2::RPK2:GFP protein fusion in the rpk2-2 background to evaluate RPK2 expression during nematode infection. Reporter expression in these transgenic lines was shown previously to reflect the cellspecific expression pattern of endogenous $R P K 2$ transcripts in a variety of tissue types (Kinoshita et al. 2010; Mizuno et al. 2007). Upon nematode infection, no detectable RPK2:GUS expression was observed during the early stages of syncytium formation at 24 to $48 \mathrm{~h}$ postinfection (hpi) (data not shown). However, a low level of GUS expression was detected in established feeding sites fed upon by parasitic J2 3 dpi (Fig. 4). Our observations of the roots of plants expressing $p R P K 2:$ : $R P K 2$ :GFP confirmed that RPK2 protein expression is restricted to the RAM and absent in other parts of the root (Fig. $5 \mathrm{~A}$ to $\mathrm{F}$ ). In nematode-infected roots, RPK2-GFP fusion protein was detected in the plasma membrane (PM) of the initial syncytial cell fed upon by parasitic J2 at 24 to 72 hpi (Fig. 5G to I) but was not detected in established feeding sites by 6 to 8 dpi (Fig. 5J to L). The sensitivity of fluorescence microscopy

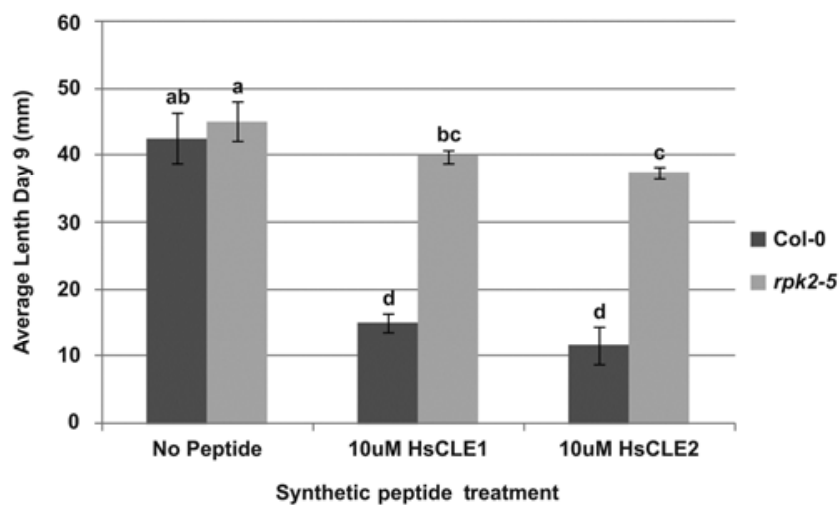

Fig. 2. Effect of cyst nematode CLAVATA3 (CLV3)/ENDOSPERM SURROUNDING REGION (CLE) peptides on $r p k 2-5$. Average length of seedlings grown for 9 days on medium with or without the indicated synthetic nematode 12-amino-acid CLE motif peptides. Data represent the mean \pm standard error, $n=11$ for each genotype. Means with different letters are significantly different $(P \leq 0.05)$. Data are representative of two biological replicates. 
coupled with the PM-localized expression of RPK2-GFP likely contributed to detection of the protein during the early stages of infection. In contrast, expression of RPK2:GUS during the early stages of syncytium formation may be below detection limits. As a control, we also infected wild-type roots and visualized them using confocal microscopy, with the same fluorescent settings, to rule out the possibility of autofluorescence induced by wounding that occurs as the nematode migrates through the root and selects a feeding cell, and the feeding cell expands. In control roots, low levels of autofluorescence were detected at only the head of the nematode or at the edges of syncytia, presumably where callose is being deposited in response to nematode infection (Fig. $5 \mathrm{M}$ to R). Taken together, these data indicate that both CLV1 and RPK2 are expressed in nematode-induced syncytia.

\section{Nematode infection is reduced on $c l v 1$ and $r p k 2$ mutants.}

An RNAi approach targeting nematode CLE genes previously showed that nematode CLE peptides are important for successful infection of host plant roots (Bakhetia et al. 2007; Patel et al. 2008). In addition, we showed that disrupting signaling through CLV2 and CRN results in a reduction in nematode infection and syncytia size. In this study, we performed a number of infection assays with different mutant alleles of $C L V 1$ and $R P K 2$ to determine whether these receptors are required for nematode CLE perception. To determine whether nematode CLE perception by CLV1 is required, we performed infection assays on the $c l v 1-4$ dominant negative allele, the clv1-20 allele that has a T-DNA insertion in the CLV1 5' untranslated region causing decreased expression of $C L V 1$, and the $c l v 1-22$ null allele. Consistent with the severity of phenotypes observed in different $\operatorname{clv} 1$ alleles, we observed a 40 to $50 \%$ reduction in nematode infection with the dominant negative allele $\operatorname{clv} 1-4(P \leq 0.05)$, a 25 to $30 \%$ reduction with the clv1-22 null allele similar to the reductions observed previously on clv2 and crn single mutants (Replogle et al. 2011), and no reduction in nematode infection with $\operatorname{clvl-20}(P=$ 0.70) (Fig. 6). This is consistent with a role for CLV1 in nematode CLE signaling and supports the hypothesis that CLV1 dominant negative alleles may interfere with other receptors that can mediate CLE signaling.

Previous studies showed that RPK2 plays a role in CLV3 signaling in the SAM (Betsuyaku et al. 2011; Kinoshita et al. 2010). To determine whether RPK 2 is involved in nematode CLE perception, we performed infection assays on the $r p k 2-5$ single mutant, as well as the rpk2-2 receptor mutant in combination with $\operatorname{clv} 1$ and $\operatorname{clv} 2$ alleles, as described by Kinoshita and associates (2010). Both clv1-101 and clv2-101 contain TDNA insertions and are presumed null alleles of CLVI and CLV2. Mutant rpk2-2 is a null allele that contains a T-DNA insertion in the LRR domain and is male sterile; therefore, it must be propagated as a heterozygote. The rpk2-2 phenotype presented a challenge for the infection assays, which had to be performed using segregating rpk2-2/+ single and clv1-101 clv2-101 rpk2-2/+ triple mutants; therefore, each individual used in the infection assay was genotyped. To do this, we inoculated seedlings at 17 days postgermination $(\mathrm{dpg})$ instead of 14 $\mathrm{dpg}$, to allow leaves to develop to a size sufficient for sampling on the day of inoculation and subsequent genotyping. No obvious differences in root morphology or growth were observed

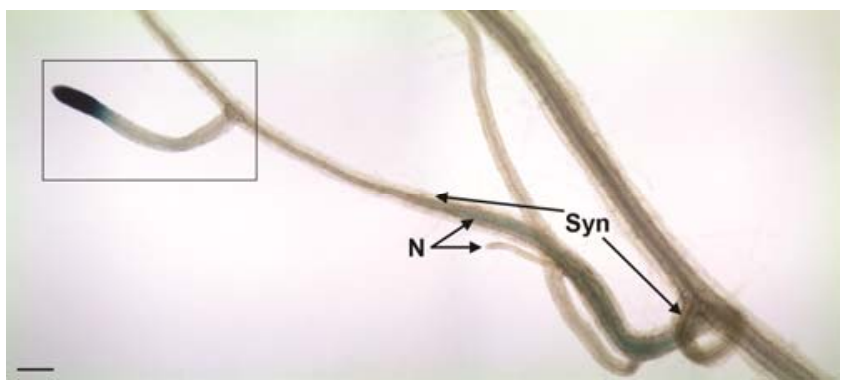

Fig. 4. RECEPTOR-LIKE PROTEIN KINASE RPK2:GUS expression during nematode infection. In Arabidopsis roots, RPK2:GUS expression is normally restricted to root tips (rectangle). At the second-stage juvenile parasitic stage, 3 days postinoculation (arrow), RPK2:GUS expression was observed in established feeding sites. Scale bar, $100 \mu \mathrm{m}$. Abbreviation: nematode, N; syncytium, Syn.
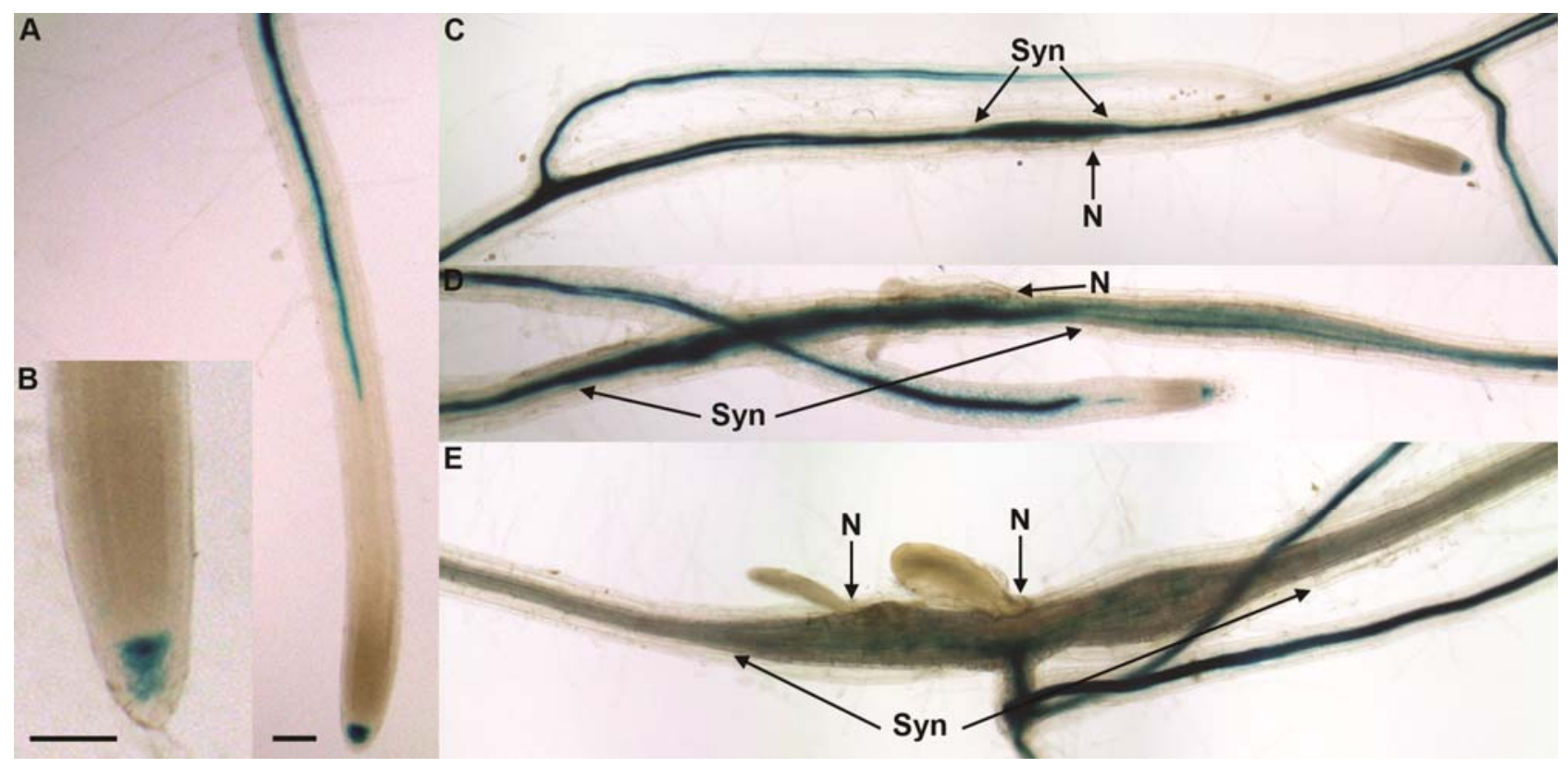

Fig. 3. Expression analysis of CLAVATA1 (CLV)1 in Arabidopsis roots and during nematode infection. A, $\beta$-Glucuronidase (GUS) expression in an uninfected Arabidopsis root. B, Close-up of GUS expression in an uninfected root tip. C, Early parasitic second-stage juvenile (J2), 2 days postinoculation (dpi). D, Late parasitic J2, 3 dpi. E, Third and fourth-stage juvenile parasitic, 7 and 10 dpi, respectively. Abbreviations: nematode, N; syncytium, Syn. Scale bars, $50 \mu \mathrm{m}$. 

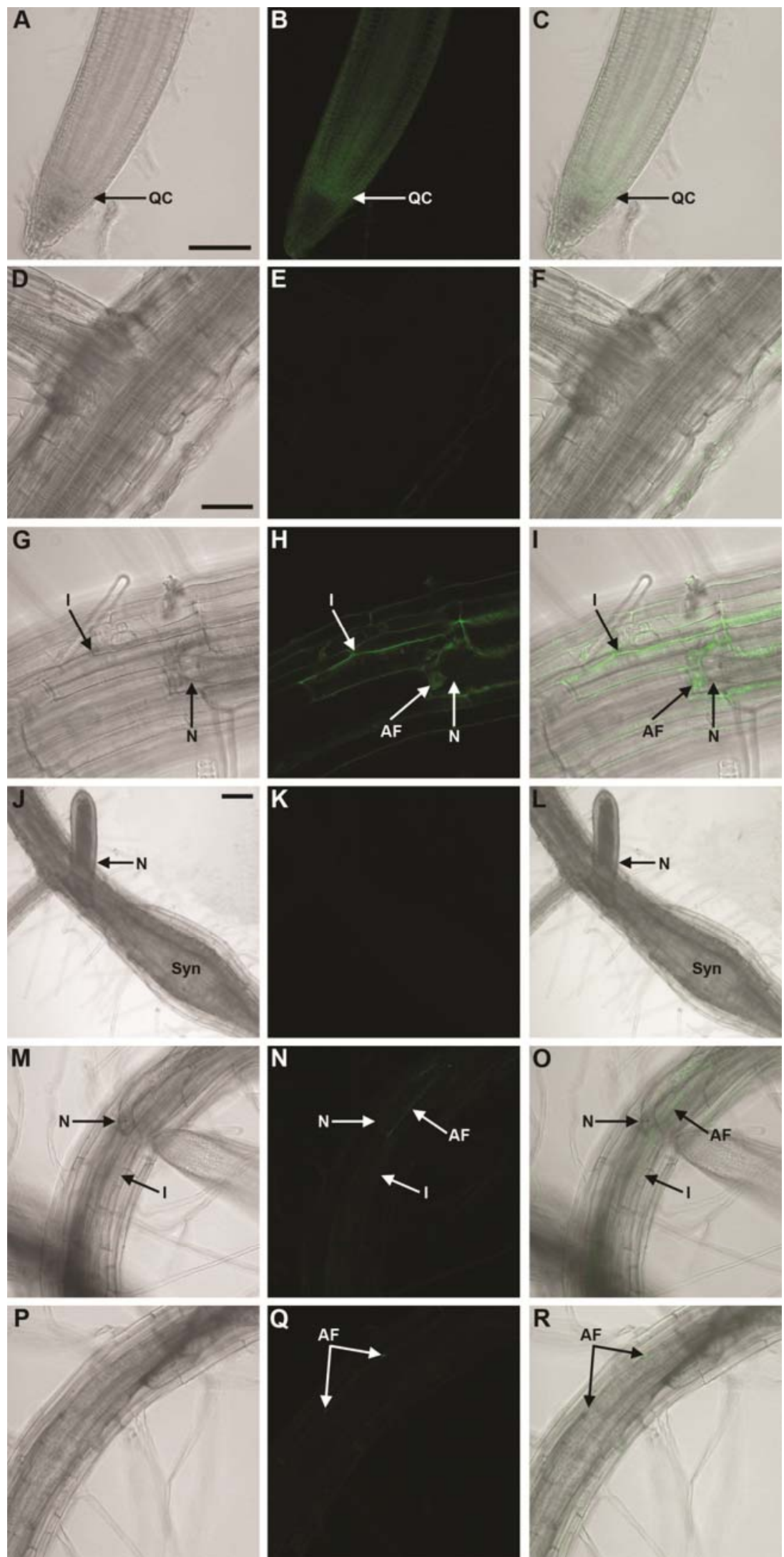

Fig. 5. Confocal images of RECEPTOR-LIKE PROTEIN KINASE 2(RPK2) expression during nematode infection. Abbreviations: quiescent center, QC; nematode, $\mathrm{N}$; initial syncytial cell, I; syncytium, Syn; autofluorescence, AF. A to $\mathbf{C}, p R P K 2: \because R P K 2: \mathrm{GFP}$ in an uninfected root tip showing protein accumulation in the root apical meristem. Scale bar, $50 \mu \mathrm{m}$. D to $\mathbf{F}, p R P K 2: \because R P K 2$ :GFP in an uninfected root section representative of where nematodes initiate feeding, showing no GFP fluorescence. Scale bar, $25 \mu \mathrm{m}$. G to I, $p R P K 2: \because R P K 2$ :GFP in response to nematode infection 24 to $48 \mathrm{~h}$ postinfection (hpi) showing some autofluorescence around the nematode head, and induction of RPK2 protein accumulation in the initial syncytial cell. See scale bar in D. J to $\mathbf{L}, p R P K 2: \because R P K 2$ :GFP in response to third-stage juvenile parasitic stage nematode 8 days postinoculation showing no protein accumulation of RPK2 in the syncytium. Scale bar, $50 \mu \mathrm{m}$. M to $\mathbf{O}$, Autofluorescence in a wild-type root around the head or migration path of the nematode at 24 to $48 \mathrm{hpi}$. See scale bar in A. $\mathbf{P}$ to $\mathbf{R}$, Little to no autofluorescence in an established syncytium of a wild-type root. See scale bar in A. 


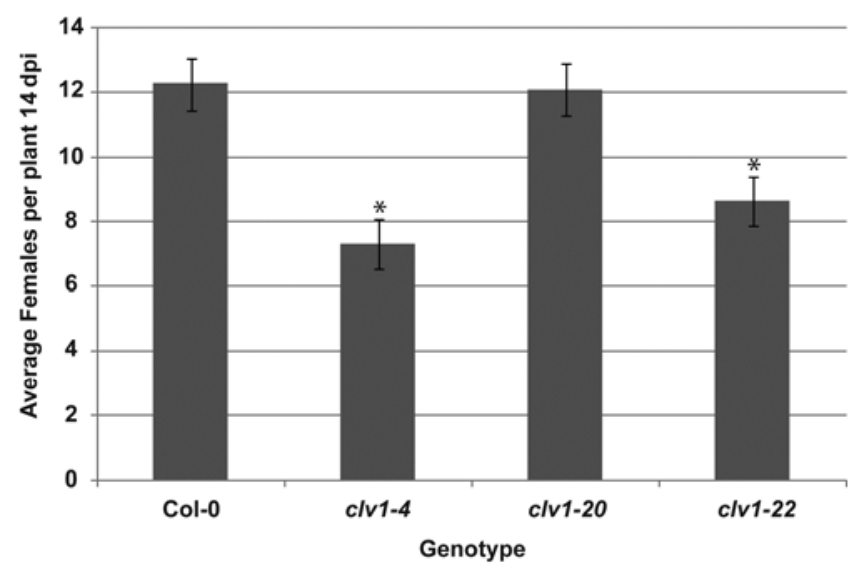

Fig. 6. Effect of CLAVATA1 (clv1) mutant alleles on Heterodera schachtii infection. Fourth-stage juvenile females were counted at 14 days postinoculation (dpi). Data represent mean \pm standard error. Means with asterisks are significantly different $(P \leq 0.05) ; n=34$ for each genotype. Data are representative of three independent experiments. on the clv1-101 clv2-101 or clv1-101 clv2-101 rpk2-2 mutants (Supplementary Fig. S1). We observed a $25 \%$ reduction in nematode infection with both rpk2 single mutants, similar to that seen with the clv1-101 and clv2-101 single mutants $(P \leq$ 0.05 ) (Fig. 7A). We observed a $30 \%$ reduction in nematode infection on the clv1-101 clv2-101 double mutant $(P \leq 0.05)$, further confirming that both CLV1 and CLV2 parallel signaling pathways are involved in nematode infection (Fig. 7A). Importantly, we reproducibly observed a 50 to $60 \%$ reduction in nematode infection on the clv1-101 clv2-101 rpk2-2 homozygous mutant $(P \leq 0.05)$ (Fig. 7A). Taken together, our data indicate that CLV1, CLV2, and RPK2 are all important for nematode infection.

Mutants $c l v 1$ and $r p k 2$ cause a reduction in syncytia size.

Because the establishment of a feeding site is required for proper nematode development and reproduction, the above observations prompted us to determine whether there were any defects in syncytia size in $c l v 1$ and $r p k 2$ mutants similar to that seen with the clv2 and crn mutants in a previous study (Replogle
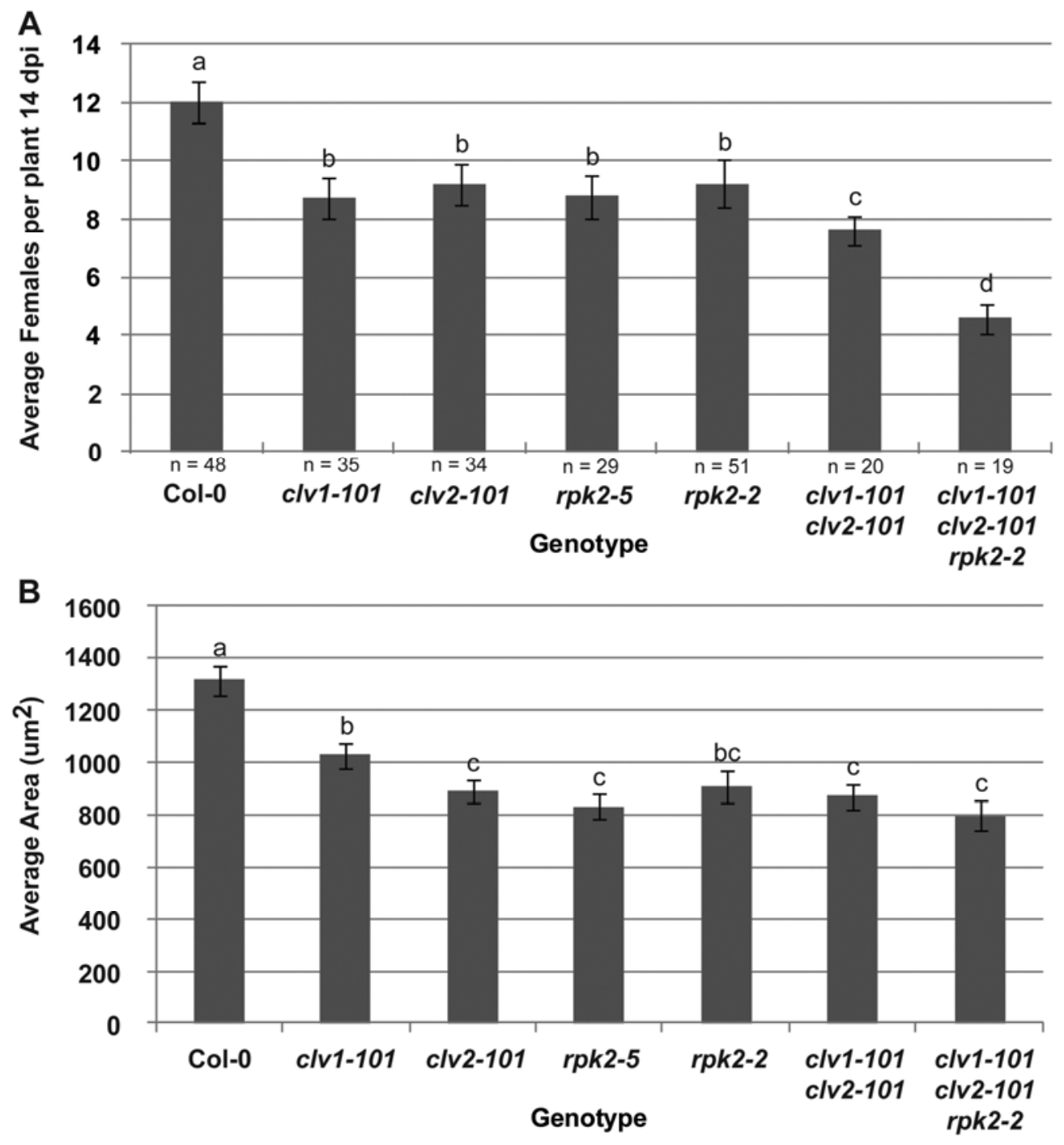

Fig. 7. Effect of CLAVATA ( $c l v) 1$, clv2, and receptor-like protein kinase2 (rpk2) mutant alleles and combinations thereof on Heterodera schachtii infection. A, Fourth-stage juvenile females were counted at 14 days postinoculation (dpi). A leaf sample was taken from each $r p k 2-2 /+$ and $c l v 1-101 \mathrm{clv} 2-101 \mathrm{rpk} 2-2 /+$ segregating seedling and genotyped for $r p k 2-2$. The resulting genotypes and corresponding single mutants, double mutants, triple mutants, 'and the wild type are represented. Data represent mean \pm standard error (SE) ( $n$ for each genotype is represented on the graph). Means with different letters are significantly different at $14 \mathrm{dpi}(P \leq 0.05)$. Data are representative of three independent experiments. B, Seedlings that were used in the 12 -well infection assay were screened at 14 dpi for syncytia that fed only one nematode and appeared translucent. Data represent mean \pm SE $(n=10$ for each genotype). Means with different letters are significantly different $(P \leq 0.05)$. 
et al. 2011). To measure syncytia size, pictures were taken of 14-dpi syncytia that were transparent and fed upon by one nematode in the 12-well plate infection assays performed above. We observed a 20 to $30 \%$ reduction in syncytia size in the single mutant alleles of $c l v 1, \operatorname{clv} 2$, and $r p k 2(P \leq 0.05)$, the clv1-101 clv2-101 double mutant $(P \leq 0.05)$, and the $c l v 1-101$ clv2-101 rpk2-2 triple mutant $(P \leq 0.05)$ (Fig. 7B). These results indicate that, although CLV1 and RPK2 play an important role in nematode success, there are clearly additional signals or CLE receptor pathways that also play a role in establishing and maintaining syncytia.

\section{DISCUSSION}

Cyst nematode CLE were found to be functional mimics of plant CLE, which are dependent on CLV2-CRN signaling for successful nematode infection and proper formation of syncytia (Bakhetia et al. 2007; Lu et al. 2009; Patel et al. 2008; Replogle et al. 2011; Wang et al. 2005, 2010, 2011). However, in our previous work, we saw only a partial reduction in nematode infection rates and syncytia size in the clv2 and crn backgrounds, which prompted us to assay additional candidate receptors. In this study, we analyzed receptor mutant alleles of CLV1 and RPK2 for their ability to perceive nematode CLE peptides and their importance in the success of the nematode to form a feeding site and complete its life cycle.

In Arabidopsis, the CLE family has 32 members (Jun et al. 2008) that have been classified into A- and B-type CLE peptides based on their ability to promote stem cell differentiation or proliferation (Whitford et al. 2008). Even though A- and B-type CLE peptides have been classified, there are only a few known or proposed signaling pathways for a subset of the plant CLE (Betsuyaku et al. 2011; Katsir et al. 2011; Meng and Feldman 2010). To date, the most well-characterized signaling pathway involves CLV3 signaling to control stem cell fate in the SAM in Arabidopsis (Katsir et al. 2011; Stahl and Simon 2010). Genetic evidence indicates that CLV1, CLV2-CRN, and RPK2 can act in parallel to transmit the CLV3 signal (Kinoshita et al. 2010). In support of the genetic data, recent reports using bioinformatics approaches, fluorescence resonance energy transfer, luciferase complementation assays, and co-immunoprecipitation experiments found that $\mathrm{CRN}$ is required for the proper localization of CLV2 to the plasma membrane and for the recruitment of CLV1 into the CRN-CLV2 complex (Betsuyaku et al. 2011; Bleckmann et al. 2010; Meng and Feldman 2010; Zhu et al. 2010). In addition, Betsuyaku and associates (2011) found that CRN is also able to promote the association of RPK2 with CLV1 and CLV2, allowing for receptor complex formation where these receptors overlap in expression for dynamic control over the response to CLV3 and other plant CLE expressed in the SAM. However, it is important to note that these studies were done in Nicotiana benthamiana, and the same trimeric complex of CLV1-CLV2-CRN has not been shown to form with coimmunoprecipitation experiments in Arabidopsis (Guo et al. 2010). Recently, various plant CLE peptides were used as cold competitors for radiolabeled CLV3 binding to CLV1, CLV2, and the related LRR-RLK BARELY ANY MERISTEM1 and MERISTEM2 (BAM1 and BAM2) (Guo et al. 2010). Arabidopsis CLE5, which has a CLE motif identical with HsCLE2 (Wang et al. 2011), was included in this study. CLE5 provided either full or partial competition to CLV3 binding for all four receptors (Guo et al. 2010), providing direct evidence that HsCLE can form a receptor-ligand complex with these and possibly other plant LRR-RLK.

Our previous studies showed that using candidate receptor mutants in exogenous peptide assays with the different nematode CLE provides a useful tool to screen for potential nema- tode CLE receptors (Replogle et al. 2011). In this study, we found that clv1-4 and rpk2-5 had reduced sensitivity to HsCLE1 and HsCLE2 peptides. In contrast, the null allele of clv1-22 was sensitive to these nematode CLE peptides. The difference in peptide sensitivity of $c l v 1-4$ versus $c l v l-22$ can be explained by the type and location of their respective mutations. The insertion in the clv1-22 allele is located 2,042 bp downstream of the predicted transcriptional start within the kinase domain of CLV1 and is a null allele. It is not surprising that the $\operatorname{clv1-22}$ null allele was sensitive to the nematode CLE peptide application because other $c l v 1$ null alleles have been shown to be sensitive to plant CLE peptide application (Fiers et al. 2005; Meng et al. 2010; Muller et al. 2008), and it is likely that CLV2-CRN or RPK2 could still transmit CLV3 in the absence of CLV1 (Dievart et al. 2003). To our knowledge, no one has conducted a peptide assay on the dominant negative $c l v 1-4$ allele side by side with the null $c l v 1-22$ allele. Here, we show that $c l v 1-4$ is actually partially resistant to HsCLE1 but not to HsCLE2. The missense mutation in $c l v 1-4$ occurs in the extracellular LRR domain, which interacts with CLE peptide ligands. Although not shown experimentally, the mutation could affect protein folding or receptor interactions and, if CLV1 mediates CLE signaling in a receptor complex with CLV2-CRN or RPK2, this could also interfere with their ability to perceive incoming CLE signals (Dievart et al. 2003). In addition, these data indicate that HsCLE may be perceived in the root by a CLV1-independent pathway.

It is unclear whether nematode CLE are signaling through existing CLE pathways in the root (i.e., those functioning in the vascular meristem or an unidentified root CLE pathway), or if they are inducing RAM- or SAM-specific pathways in feeding sites. One approach to begin dissecting this is to visualize expression of the candidate receptors during the course of nematode infection. In uninfected roots, $C L V 1$ was found to be expressed throughout the vasculature, except in the zone of elongation, and present in the root tip. Upon nematode infection, CLV1 remained on and even increased in expression in feeding sites of parasitic $\mathrm{J} 2$. This is consistent with a role in nematode CLE perception and indicates that nematodes might be tapping into existing CLE pathways involving CLV1 that have not yet been identified in the root. The observed downregulation of $C L V 1-G U S$ in syncytia at later time points is consistent with a prior microarray study reporting a threefold downregulation of $C L V 1$ in microaspirated syncytia at 5 and 15 dpi compared with uninfected Arabidopsis root tissues (Szakasits et al. 2009). In contrast to $C L V 1$ expression, $R P K 2$ expression and RPK2 protein accumulation is restricted to the RAM in uninfected roots. Upon nematode infection, however, RPK2 protein accumulation occurred in the plasma membrane of cells selected for syncytium formation. This induction occurs as early as $24 \mathrm{hpi}$ and expression continues up to $72 \mathrm{hpi}$; however, protein accumulation was undetectable thereafter. Likewise, differential expression of RPK2 was not detected in microaspirated syncytia at 5 and 15 dpi compared with uninfected Arabidopsis root tissues (Szakasits et al. 2009). This provides evidence that the nematode may need to induce RAM- or SAM-specific pathways to initiate feeding site formation but that RPK2 signaling is not needed for maintenance of the syncytium. The involvement of different receptor complexes for different phases of organogenesis was also observed in normal Arabidopsis development. Shoot meristems appear to utilize parallel signaling pathways of CLV1-BAM and CLV2-CRN, while CLV1-CLV2-CRN complex formation is required for proper fruit development (Durbak and Tax 2011). Instead of nematode CLE receptors being localized to the outer plasma membrane of the developing feeding site, it is possible that they are localized in the cells adjacent to the expanding syncy- 
tium, because nematode CLE are redirected to the host root apoplast (Wang et al. 2010). Therefore, nematode CLE signaling could interact with extracellular receptors of the adjacent cells that are primed for incorporation to trigger pathways needed to properly form the syncytium.

Previous studies demonstrated that SCN and BCN CLE are important for nematode parasitism as a result of knocking down CLE expression in the worm using RNAi approaches or disrupting CLE perception with receptor mutants (Bakhetia et al. 2007; Patel et al. 2008; Replogle et al. 2011). To directly test for a role of CLV1 or RPK2 in nematode CLE perception, we performed infection assays on the corresponding receptor mutants. We showed a reduction in nematode infection on all of the receptor mutants tested. Significantly, we showed further reduction in nematode infection when $r p k 2$ was combined with $\operatorname{clv} 1$ and $\operatorname{clv} 2$ mutants. We also saw a reduction in syncytia size with $c l v 1$ and rpk2 mutants but we did not see further reduction in double and triple mutants, indicating that additional signals, possibly outside of CLE signaling, are required for syncytia formation.

The involvement of CLV1 and RPK2 in nematode CLE signaling or perception may shed some light onto how nematodes are tapping into existing signaling pathways to promote pathogenesis. Recently, it was found that perception of CLV3 by CLV1 activates mitogen-activated protein kinases (MPK) MPK3 and MPK6 signaling (Betsuyaku et al. 2011; Lee et al. 2011), which has been shown to be involved in mediating developmental and stress signaling in Arabidopsis (Cho et al. 2008; Heese et al. 2007; H. Wang et al. 2007). Future studies will need to be conducted to determine if nematode CLE signaling is interfering with the plant innate immune response to promote pathogenesis or if nematode CLE signaling is tapping into the developmental side of MPK signaling to promote feeding site formation. It is also possible that both CLE-mediated defense suppression and induction of developmental pathways are needed for successful nematode infection.

RPK2 is involved in several developmental processes, including embryo pattern formation, anther development, and meristem maintenance in the SAM and RAM (Kinoshita et al. 2010; Mizuno et al. 2007; Nodine et al. 2007). While studying the role of RPK2, Mizuno and associates (2007) found that $r p k 2$ mutants were downregulated in many genes encoding metabolic enzymes, including those involved in cell wall metabolism. During feeding cell formation, the initial syncytial cell goes through significant cell wall remodeling and metabolic reprogramming to support the energy requirements of the nematode (Hofmann et al. 2010a; Ithal et al. 2007; Szakasits et al. 2009), which supports a role for RPK2 signaling during nematode infection.

To date, the exact function of nematode CLE proteins during the infection process and their involvement in syncytia formation is unresolved. However, this study and our previous work (Replogle et al. 2011) have shown that CLV1, CLV2-CRN, and RPK2 are important for nematode CLE signaling and, ultimately, success of the nematode to complete its life cycle. These findings allow future studies to begin identifying downstream signaling components that are regulated by these receptors. Downstream signaling pathways for plant CLE signaling are currently under intensive investigation, especially in the SAM, where ligand induced receptor endocytosis, MPK activation, protein phosphorylation, and cytokinin signaling have all been shown to play a role in stem cell maintenance (Katsir et al. 2011; Stahl and Simon 2010). In addition, there are other RAM-specific CLE signaling pathways which may be involved in nematode CLE perception that warrant further investigation. For example, in the RAM, CLE40 restricts the expression of WOX5 in an ACR4-dependent manner (Sarkar et al. 2007; Stahl et al. 2009). The identification of receptors involved in nematode CLE signaling in Arabidopsis enables us to begin identifying the orthologs in agriculturally important crops for the development of engineered host resistance to cyst nematodes.

\section{MATERIALS AND METHODS}

\section{Peptide assays.}

Arabidopsis seed were sterilized using the chlorine gas method (Wang et al. 2011). Sterilized seed were germinated on vertical plates in a growth chamber at $22^{\circ} \mathrm{C}$ under long-day conditions ( $16 \mathrm{~h}$ of light and $8 \mathrm{~h}$ of darkness) containing synthetic peptides (Sigma-Aldrich, St. Louis) as previously described (Wang et al. 2011). The $c l v 1-101$, clv2-101, and rpk2$2 /+$ singles, the clv1-101 clv2-101 double, and the clv1-101 clv2-101 rpk2-2/+ segregating triple mutants are described by Kinoshita and associates (2010). The rpk2-5 allele was provided by Shinichiro Sawa. The $c l v 1-4, \operatorname{clv} 1-20$, and $\operatorname{clv} 1-22$ mutants are described by Durbak and Tax (2011). The clv1101 (Kinoshita et al. 2010) and clv1-22 (Durbak and Tax 2011) mutants are the same alleles. Beginning at 2 days after germination, root length was marked each day for 9 to 12 days. Plates were scanned using an Epson Perfection V200 PHOTO scanner and total root length was determined using Scion Image. Statistical analysis was conducted by Student's $t$ test in Excel.

\section{Reporter lines.}

The CLV1:GUS transgenic lines (J-1-16 and J-1-18) used in this study were previously described and characterized in $\mathrm{Arabi}$ dopsis fruit formation (Durbak and Tax 2011). The RPK2:GUS (line 6-37-A) and pRPK2::RPK2-GFP (line E1b 1-1-6) transgenic lines have been previously described and characterized in the SAM and RAM (Kinoshita et al. 2010).

\section{Nematode infection on reporter lines.}

The BCN H. schachtii was propagated on greenhouse-grown sugar beet (Beta vulgaris 'Monohi'). BCN eggs were isolated and hatched as previously described (Mitchum et al. 2004). After 2 days, J2 were collected and surface sterilized according to X. Wang and associates (2007), except that $0.004 \%$ mercuric chloride, $0.004 \%$ sodium azide, and $0.002 \%$ Triton $\mathrm{X}-100$ were used. Sterilized seed were grown on modified Knop's medium with Daishin agar (Brunschwig Chemie, Amsterdam, The Netherlands) (Sijmons et al. 1991). Ten days after germination, seedlings were inoculated with 20 sterilized J2 per root.

\section{Histochemical GUS assays.}

CLV1:GUS and RPK2:GUS lines were sterilized, grown, and inoculated with nematodes as described above. At the indicated time points, freshly excised tissues were infiltrated with GUS substrate buffer (0.5 mM 5-bromo-4chloro-3-indolyl glucuronide, $100 \mathrm{mM}$ Tris [pH 7.0], $50 \mathrm{mM} \mathrm{NaCl}$, and $0.06 \%$ Triton X-100) containing $1.5 \mathrm{mM}$ potassium ferricyanide (CLV1:GUS) or no potassium ferricyanide (RPK2:GUS) and incubated overnight at $37^{\circ} \mathrm{C}$ (Jefferson et al. 1987). Stained roots were placed in glass petri dishes and visualized with a Nikon Eclipse TS100 inverted microscope (Nikon, Melville, NY, U.S.A.).

\section{Confocal microscopy.}

$p R P K 2: \because R P K 2-G F P$ seed was sterilized, grown, and inoculated with nematodes as described above. At the indicated time points, infected roots were mounted on glass slides and visualized with a 510 META confocal scanning microscope (Carl Zeiss, Thornwood, NY, U.S.A.) excited at $488 \mathrm{~nm}$ with an emission band pass filter of 500 to $550 \mathrm{~nm}$. 
Infection assay with receptor mutants.

Sterilized receptor mutants were plated in 12-well Falcon tissue culture plates (BD Biosciences, San Jose, CA, U.S.A.) containing modified Knop's medium with $0.8 \%$ Daishin agar in a randomized block design. Plants were grown at $24^{\circ} \mathrm{C}$ with a 12-h photoperiod. At $14 \mathrm{dpg}$, seedlings were inoculated with 200 surface-sterilized BCN J2. For infection assays involving mutants segregating for $r p k 2-2$, leaf samples were collected at $17 \mathrm{dpg}$ for genomic DNA, using the cetyltrimethylammonium bromide method, and seedlings were subsequently inoculated as described above. Primers used to genotype for $r p k 2-2$ were as follows: SALK_039514LP 5'-GCCTTCTCGGTAAAGAA GGAG-3' and SALK_039514RP 5'-GTAGGAATCTGGGGA ATGGAG-3' for the gene specific primer set, and LBSKA 5'GATTTCGGAACCACCATCAAAC- $3^{\prime}$ to detect the T-DNA insertion. $\mathrm{J} 4$ females were counted at 14 days postinoculation (dpi) and adult females were counted at 30 dpi. The average values were calculated and significant differences were determined with SAS $(P \leq 0.05)$. At 14 dpi, syncytia from the 12 well plate infection assay that were transparent and only fed upon by one nematode were visualized with an Olympus SZ60 dissecting microscope (Olympus, Center Valley, PA, U.S.A.) and photographed using a Nikon COOLPIX 5000 digital camera. The syncytia were outlined using AxioVision Release 4.8 (Carl Zeiss) and the area of the longitudinal section was calculated by the software. Significant differences were determined by using Student's $t$ test $(P \leq 0.05)$. These approaches are similar to what others have recently done to measure the area of syncytia (Hofmann et al. 2010b; Replogle et al. 2011; Siddique et al. 2009).

\section{ACKNOWLEDGMENTS}

We thank R. Heinz for the maintenance of the nematode cultures and J. Mercurio at MU Molecular Cytology Core for help with imaging. This work was supported by a National Science Foundation (NSF) CAREER grant (grant number NSF IBN-0347675 to F. E. Tax), the United States Department of Agriculture (USDA)-National Research Initiative Competitive Grants Program (grant number 2009-35302-05304 to M. G. Mitchum and X. Wang), a USDA Special Grant (grant number 2008-34113-19420 to M. G. Mitchum), and an MU Life Sciences Fellowship to A. Replogle.

\section{LITERATURE CITED}

Bakhetia, M., Urwin, P. E., and Atkinson, H. J. 2007. QPCR analysis and RNAi define pharyngeal gland cell-expressed genes of Heterodera glycines required for initial interactions with the host. Mol. Plant-Microbe Interact. 20:306-312.

Betsuyaku, S., Takahashi, F., Kinoshita, A., Miwa, H., Shinozaki, K., Fukuda, H., and Sawa, S. 2011. Mitogen-activated protein kinase regulated by the CLAVATA receptors contributes to shoot apical meristem homeostasis. Plant Cell Physiol. 52:14-29.

Bleckmann, A., Weidtkamp-Peters, S., Seidel, C. A., and Simon, R. 2010. Stem cell signaling in Arabidopsis requires CRN to localize CLV2 to the plasma membrane. Plant Physiol. 152:166-176.

Birnbaum, K., Shasha, D. E., Wang, J. Y., Jung, J. W., Lambert, G. M., Galbraith, D. W., and Benfey, P. N. 2003. A gene expression map of the Arabidopsis root. Science 302:1956-1960.

Brady, S. M., Orlando, D. A., Lee, J.-Y., Wang, J. Y., Koch, J., Dinneny, J. R., Mace, D., Ohler, U., and Benfey, P. N. 2007. A high-resolution root spatiotemporal map reveals dominant expression patterns. Science 318:801-806.

Brand, U., Fletcher, J. C., Hobe, M., Meyerowitz, E. M., and Simon, R. 2000. Dependence of stem cell fate in Arabidopsis on a feedback loop regulated by CLV3 activity. Science 289:617-619.

Casamitjana-Martinez, E., Hofhuis, H.F., Xu, J., Liu, C. M., Heidstra, R., and Scheres, B. 2003. Root-specific CLE19 overexpression and the soll/2 suppressors implicate a CLV-like pathway in the control of Arabidopsis root meristem maintenance. Curr. Biol. 13:1435-1441.

Cho, S. K., Larue, C. T., Chevalier, D., Wang, H., Jinn, T. L., Zhang, S., and Walker, J. C. 2008. Regulation of floral organ abscission in Arabidopsis thaliana. Proc. Natl. Acad. Sci. U.S.A. 105:15629-15634.

Clark, S. E., Running, M. P., and Meyerowitz, E. M. 1993. CLAVATA1, a regulator of meristem and flower development in Arabidopsis. Development 119:397-418.

Clark, S. E., Running, M. P., and Meyerowitz, E. M. 1995. CLAVATA3 is a specific regulator of shoot and floral meristem development affecting the same processes as CLAVATA1. Development 121:2057-2067.

Clark, S. E., Williams, R. W., and Meyerowitz, E. M. 1997. The CLAVATA1 gene encodes a putative receptor kinase that controls shoot and floral meristem size in Arabidopsis. Cell 89:575-585.

Cock, J. M., and McCormick, S. 2001. A large family of genes that share homology with CLAVATA3. Plant Physiol. 126:939-942.

Davis, E. L., Hussey, R. S., Mitchum, M. G., and Baum, T. J. 2008. Parasitism proteins in nematode-plant interactions. Curr. Opin. Plant Biol. 11:360-366.

Dievart, A., Dalal, M., Tax, F. E., Lacey, A. D., Huttly, A., Li, J., and Clark, S. E. 2003. CLAVATA1 dominant-negative alleles reveal functional overlap between multiple receptor kinases that regulate meristem and organ development. Plant Cell 15:1198-1211.

Durbak, A. R., and Tax, F. E. 2011. CLAVATA signaling pathway receptors of Arabidopsis regulate cell proliferation in fruit organ formation as well as in meristems. Genetics 189:177-194.

Etchells, J. P., and Turner, S. R. 2010. The PXY-CLE41 receptor ligand pair defines a multifunctional pathway that controls the rate and orientation of vascular cell division. Development 137:767-774.

Fiers, M., Hause, G., Boutilier, K., Casamitjana-Martinez, E., Weijers, D., Offringa, R., van der Geest, L., van Lookeren Campagne, M., and Liu, C. M. 2004. Mis-expression of the CLV3/ESR-like gene CLE19 in Arabidopsis leads to a consumption of root meristem. Gene 327:37-49.

Fiers, M., Golemiec, E., Xu, J., van der Geest, L., Heidstra, R., Stiekema, W., and Liu, C. M. 2005. The 14-amino acid CLV3, CLE19, and CLE40 peptides trigger consumption of the root meristem in Arabidopsis through a CLAVATA2-dependent pathway. Plant Cell 17:2542-2553.

Fletcher, L. C., Brand, U., Running, M. P., Simon, R., and Meyerowitz, E. M. 1999. Signaling of cell fate decisions by CLAVATA3 in Arabidopsis shoot meristems. Science 283:1911-1914.

Gheysen, G., and Mitchum, M. G. 2011. How nematodes manipulate plant development pathways for infection. Curr. Opin. Plant Biol. 14:415421.

Guo, Y., Han, L., Hymes, M., Denver, R., and Clark, S. E. 2010. CLAVATA2 forms a distinct CLE-binding receptor complex regulating Arabidopsis stem cell specification. Plant J. 63:889-900.

Heese, A., Hann, D. R., Gimenez-Ibanez, S., Jones, A. M., He, K., Li, J., Schroeder, J. I., Peck, S. C., and Rathjen, J. P. 2007. The receptor-like kinase SERK3/BAK1 is a central regulator of innate immunity in plants. Proc. Natl. Acad. Sci. U.S.A. 104:12217-12222.

Hirakawa, Y., Shinohara, H., Kondo, Y., Inoue, A., Nakanomyo, I., Ogawa, M., Sawa, S., Ohashi-Ito, K., Matsubayashi, Y., and Fukuda, H. 2008. Non-cell-autonomous control of vascular stem cell fate by a CLE peptide/receptor system. Proc. Natl. Acad. Sci. U.S.A. 105:15208-15213.

Hofmann, J., El Ashry, A. N., Anwar, S., Erban, A., Kopka, J., and Grundler, F. M. 2010a. Metabolic profiling reveals local and systemic responses of host plants to nematode parasitism. Plant J. 62:1058-1071.

Hofmann, J., Youssef-Banora, M., de Almeida-Engler, J., and Grundler, F. M. 2010b. The role of callose deposition along plasmodesmata in nematode feeding sites. Mol. Plant-Microbe Interact. 23:549-557.

Hussey, R. S., and Grundler, F. M. W. 1998. Nematode parasitism of plants. Pages 213-243 in: The Physiology and Biochemistry of FreeLiving and Plant-Parasitic Nematodes. N. S. Iacobellis, Collmer, A., Hutcheson, S. W., Mansfield, J. W., Morris, C. E., Murillo J., Schaad, N. W., Stead, D. E., Surico, G., and Ullrich, M, eds. Kluwer Academic CABI Publishing, Dordrecht, The Netherlands.

Ithal, N., Recknor, J., Nettleton, D., Maier, T., Baum, T. J., and Mitchum, M. G. 2007. Developmental transcript profiling of cyst nematode feeding cells in soybean roots. Mol. Plant-Microbe Interact. 20:510-525.

Ito, Y., Nakanomyo, I., Motose, H., Iwamoto, K., Sawa, S., Dohmae, N., and Fukuda, H. 2006. Dodeca-CLE peptides as suppressors of plant stem cell differentiation. Science 313:842-845.

Jefferson, R. A., Kavanagh, T. A., and Bevan, M. W. 1987. GUS fusions: $\beta$-Glucuronidase as a sensitive and versatile gene fusion marker in higher plants. EMBO (Eur. Mol. Biol. Organ.) J. 6:3901-3907.

Jun, J. H., Fiume, E., and Fletcher, J. C. 2008. The CLE family of plant polypeptide signaling molecules. Cell. Mol. Life Sci. 65:743-755.

Jun, J., Fiume, E., Roeder, A. H., Meng, L., Sharma, V. K., Osmont, K. S., Baker, C., Ha, C. M., Meyerowitz, E. M., Feldman, L. J., and Fletcher, J. C. 2010. Comprehensive analysis of CLE polypeptide signaling gene expression and overexpression activity in Arabidopsis. Plant Physiol. 154:1721-1736.

Katsir, L., Davies, K. A., Bergmann, D. C., and Laux, T. 2011. Peptide signaling in plant development. Curr. Biol. 21:R356-R364.

Kinoshita, A., Betsuyaku, S., Osakabe, Y., Mizuno, S., Nagawa, S., Stahl, Y., Simon, R., Yamaguchi-Shinozaki, K., Fukuda, H., and Sawa, S. 
2010. RPK2 is an essential receptor-like kinase that transmits the CLV3 signal in Arabidopsis. Development 137:3911-3920.

Lee, H., Chah, O. K., and Sheen, J. 2011. Stem-cell-triggered immunity through CLV3p-FLS2 signalling. Nature 473:376-379.

Lu, S. W., Chen, S., Wang, J., Yu, H., Chronis, D., Mitchum, M. G., and Wang, X. 2009. Structural and functional diversity of CLAVATA3/ESR (CLE)-like genes from the potato cyst nematode Globodera rostochiensis. Mol. Plant-Microbe Interact. 22:1128-1142.

McKelvie, A. D. 1962. A list of mutant genes in Arabidopsis thaliana (L.) Heynh. Rad. Bot. 1:233-240.

Meng, L., and Feldman, L. J. 2010. CLE14/CLE20 peptides may interact with CLAVATA2/CORYNE receptor-like kinases to irreversibly inhibit cell division in the root meristem of Arabidopsis. Planta 232:10611074.

Meng, L., Ruth, K. C., Fletcher, J. C., and Feldman, L. 2010. The roles of different CLE domains in Arabidopsis CLE polypeptide activity and functional specificity. Mol. Plant 3:760-772.

Mitchum, M. G., Sukno, S., Wang, X., Shani, Z., Tsabary, G., Shoseyov, O., and Davis, E. L. 2004. The promoter of the Arabidopsis thaliana Cell endo-1,4-beta glucanase gene is differentially expressed in plant feeding cells induced by root-knot and cyst nematodes. Mol. Plant Pathol. 5:175-181.

Miwa, H., Betsuyaku, S., Iwamoto, K., Kinoshita, A., Fukuda, H., and Sawa, S. 2008. The receptor-like kinase SOL2 mediates CLE signaling in Arabidopsis. Plant Cell Physiol. 49:1752-1757.

Mizuno, S., Osakabe, Y., Maruyama, K., Ito, T., Osakabe, K., Sato, T., Shinozaki, K., and Yamaguchi-Shinozaki, K. 2007. Receptor-like protein kinase 2 (RPK2) is a novel factor controlling anther development in Arabidopsis thaliana. Plant J. 50:751-766.

Muller, R., Bleckmann, A., and Simon, R. 2008. The receptor kinase CORYNE of Arabidopsis transmits the stem cell-limiting signal CLAVATA3 independently of CLAVATA1. Plant Cell 20:934-946.

Nodine, M. D., Yadegari, R., and Tax, F. E. 2007. RPK1 and TOAD2 are two receptor-like kinases redundantly required for Arabidopsis embryonic pattern formation. Dev. Cell 12:943-956.

Ogawa, M., Shinohara, H., Sakagami, Y., and Matsubayashi, Y. 2008. Arabidopsis CLV3 peptide directly binds CLV1 ectodomain. Science 319:294.

Olsen, A. N., and Skriver, K. 2003. Ligand mimicry? Plant-parasitic nematode polypeptide with similarity to CLAVATA3. Trends Plant Sci. 8:5557.

Patel, N., Hamamouch, N., Chunying, L., Hussey, R., Mitchum, M. Baum, T., Wang, X., and Davis, E. L. 2008. Similarity and functional analyses of expressed parasitism genes in Heterodera schachtii and Heterodera glycines. J. Nematol. 40:299-310.

Reddy, G. V., and Meyerowitz, E. M. 2005. Stem-cell homeostasis and growth dynamics can be uncoupled in the Arabidopsis shoot apex. Science 310:663-667.

Replogle, A., Wang, J., Bleckmann, A., Hussey, R. S., Baum, T. J., Sawa, S., Davis, E. L., Wang, X., Simon, R., and Mitchum, M. G. 2011. Nematode CLE signaling in Arabidopsis requires CLAVATA2 and CORYNE. Plant J. 65:430-440.

Sarkar, A. K., Luijten, M., Miyashima, S., Lenhard, M., Hashimoto, T. Nakajima, K., Scheres, B., Heidstra, R., and Laux, T. 2007. Conserved factors regulate signalling in Arabidopsis thaliana shoot and root stem cell organizers. Nature 446:811-814.

Schoof, H., Lenhard, M., Haecker, A., Mayer, K. F., Jurgens, G., and Laux, T. 2000. The stem cell population of Arabidopsis shoot meristems in maintained by a regulatory loop between the CLAVATA and WUSCHEL genes. Cell 100:635-644.

Sharma, V. K., Ramirez, J., and Fletcher, J. C. 2003. The Arabidopsis $C L V 3$-like $(C L E)$ genes are expressed in diverse tissues and encode secreted proteins. Plant Mol. Biol. 51:415-425.

Shiu, S. H., and Bleecker, A. B. 2001. Receptor-like kinases from Arabidopsis form a monophyletic gene family related to animal receptor kinases. Proc. Natl. Acad. Sci. U.S.A. 98:10763-10768.
Siddique, S., Endres, S., Atkins, J. M., Szakasits, D., Wieczorek, K. Hofmann, J., Blaukopf, C., Urwin, P. E., Tenhaken, R., Grundler, F. M., Kreil, D. P., and Bohlmann, H. 2009. Myo-inositol oxygenase genes are involved in the development of syncytia induced by Heterodera schachtii in Arabidopsis roots. New Phytol. 184:457-472.

Sijmons, P. C., Grundler, F. M. W., Vonmende, N., Burrows, P. R., and Wyss, U. 1991. Arabidopsis thaliana as a new model host for plant parasitic nematodes. Plant J. 1:245-254.

Sobczak, M., Avrova, A., Jupowicz, J., Phillips, M. S., Ernst, K., and Kumar, A. 2005. Characterization of susceptibility and resistance responses to potato cyst nematode (Globodera spp.) infection of tomato lines in the absence and presence of the broad-spectrum nematode resistance Hero gene. Mol. Plant-Microbe Interact. 18:158-168.

Stahl, Y., and Simon, R. 2010. Plant primary meristems: Shared functions and regulatory mechanisms. Curr. Opin. Plant Biol. 13:53-58.

Stahl, Y., Wink, R. H., Ingram, G. C., and Simon, R. 2009. A signaling module controlling the stem cell niche in Arabidopsis root meristems. Curr. Biol. 19:909-914.

Strabala, T. J., O’Donnell, P. J., Smit, A. M., Ampomah-Dwamena, C., Martin, E. J., Netzler, N., Nieuwenhuizen, N. J., Quinn, B. D., Foote, H. C. C., and Hudson, K. R. 2006. Gain-of-function phenotypes of many CLAVATA3/ESR genes, including four new family members, correlate with tandem variations in the conserved CLAVATA3/ESR domain. Plant Physiol. 140:1331-1344.

Szakasits, D., Heinen, P., Wieczorek, K., Hofmann, J., Wagner, F., Kreil, D. P., Sykacek, P., Grundler, F. M., and Bohlmann, H. 2009. The transcriptome of syncytia induced by the cyst nematode Heterodera schachtii in Arabidopsis roots. Plant J. 57:771-784.

Wang, H., Ngwenyama, N., Liu, Y., Walker, J. C., and Zhang, S. 2007. Stomatal development and patterning are regulated by environmentally responsive mitogen-activated protein kinases in Arabidopsis. Plant Cell 19:63-73.

Wang, J., Lee, C., Replogle, A., Joshi, S., Korkin, D., Hussey, R., Baum, T. J., Davis, E. L., Wang, X., and Mitchum, M. G. 2010. Dual roles for the variable domain in protein trafficking and host-specific recognition of Heterodera glycines CLE effector proteins. New Phytol. 187:10031017.

Wang, J., Replogle, A., Hussey, R., Baum, T., Wang, X., Davis, E. L., and Mitchum, M. G. 2011. Identification of potential host plant mimics of CLV3/ESR (CLE)-like peptides from the plant-parasitic nematode Heterodera schachtii. Mol. Plant Pathol. 12:177-186.

Wang, X., Mitchum, M. G., Gao, B., Li, C., Diab, H., Baum, T. J., Hussey, R. S., and Davis, E. L. 2005. A parasitism gene from a plant-parasitic nematode with function similar to CLAVATA3/ESR (CLE) of Arabidopsis thaliana. Mol. Plant Pathol. 6:187-191.

Wang, X., Replogle, A., Davis, E. L., and Mitchum, M. G. 2007. The tobacco $\mathrm{Cel} 7$ gene promoter is auxin-responsive and locally induced in nematode feeding sites of heterologous plants. Mol. Plant Pathol. 8:423-436.

Whitford, R., Fernandez, A., De Groodt, R., Ortega, E., and Hilson, P. 2008. Plant CLE peptides from two distinct functional classes synergistically induce division of vascular cells. Proc. Natl. Acad. Sci. U.S.A. 105:18625-18630.

Yadav, R. K., Tavakkoli, M., and Reddy, G. V. 2010. WUSCHEL mediates stem cell homeostasis by regulating stem cell number and patterns of cell division and differentiation of stem cell progenitors. Development 137:3581-3589.

Zhu, Y., Wang, Y., Li, R., Song, X., Wang, Q., Huang, S., Jin, J. B., Liu, C. M., and Lin, J. 2010. Analysis of interactions among the CLAVATA3 receptors reveals a direct interaction between CLAVATA2 and CORYNE in Arabidopsis. Plant J. 61:223-233.

\section{AUTHOR-RECOMMENDED INTERNET RESOURCE}

The Arabidopsis Gene Expression database: www.arexdb.org 